\title{
Información y Novedades
}

\section{EVENTOS}

- El Jubileo de Diamante del Congreso de la Sociedad Anatómica de India: Cuttack, India, 27 al 29 de diciembre de 2012 (ver invitación a continuación).

- $5^{\circ}$ Simposio Internacional de Anatomía Clínica y Aplicada y Primer Encuentro Paneuropeo de Anatomistas: Graz, Austria, 24 al 26 de mayo de 2013. (Ver a continuación)

- $\quad 1^{\circ}$ Congreso de la Asociación Europea de Anatomía Clínica: Lisboa, Portugal, junio 2013 (ver invitación a continuación).

- $\quad$ III Congreso Argentino de Anatomía Clínica: Mendoza, Argentina, setiembre 2013.

- $\quad 18^{\circ}$ Congreso de la Federación Internacional de Asociaciones de Anatomistas (IFAA): Beijing, China, 8 al 10 de agosto de 2014. www.bicc.com.cn y www.bcghotel.com.

\section{CONVOCATORIA}

\section{PORTADA DE LA REVISTA}

Invitamos a todos suscriptos a la Revista Argentina de Anatomía Clínica y a los miembros de la Asociación Argentina de Anatomía Clínica a enviar imágenes (fotografías, dibujos, caricaturas, etc.) para ser incluidas en la portada de la Revista.

Las imágenes deberán ser originales, relacionadas a la Anatomía Clínica, a la Educación Médica en Anatomía, a los contenidos o actividades de la Revista Argentina de Anatomía Clínica o a las actividades de Asociación Argentina de Anatomía Clínica; poseer buena calidad a los fines de su edición, adaptarse al espacio disponible, no haber sido publicadas de modo formal o informal (internet) con antelación, contar con título y nombre del autor.

Se enviarán a través del sitio web de la Revista. Serán seleccionadas por el/la Editor en Jefe y el Consejo Editorial. En caso de considerarse conveniente, se podrá dar participación a los suscriptores. Sus imágenes encabezarán los próximos números.

Prof. Dra. Susana N. Biasutto

Editor en Jefe

Revista Argentina de Anatomía Clínica 


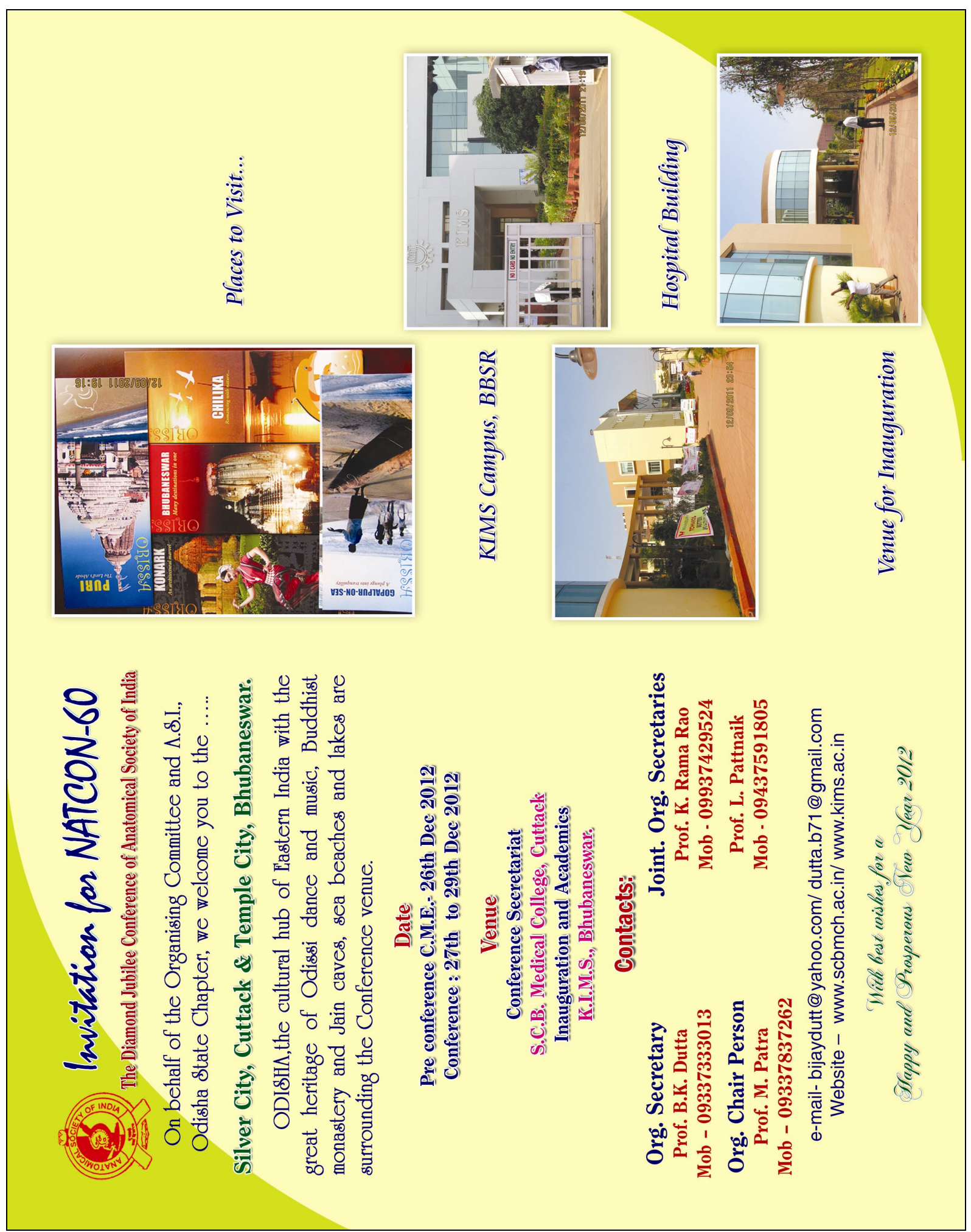




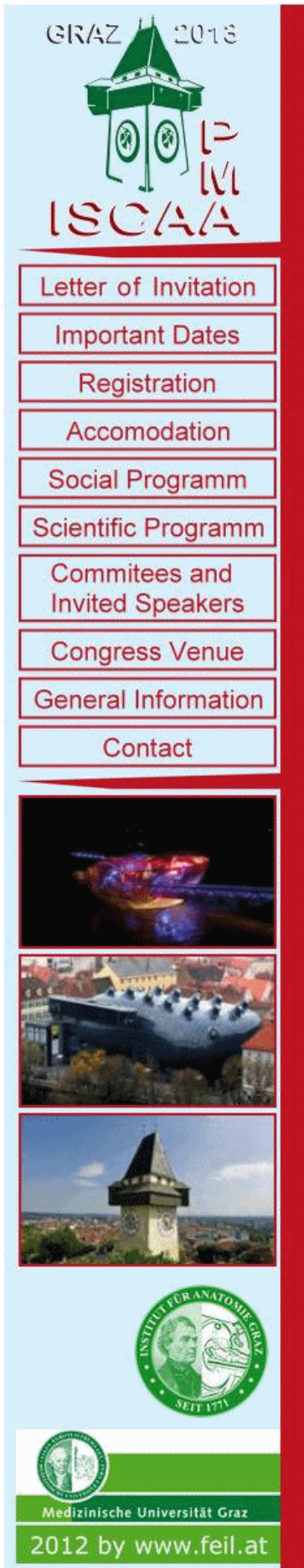

\section{5th International Symposion of Clinical and Applied Anatomy}

\author{
1st Paneuropean Meeting of
}

Anatomists
Dear colleagues, participants, guests and friends,

On behalf of the organizing team of the Institute of Anatomy, I am, as Congress President, proud to invite you to the 5th International Symposium of Clinical and Applied Anatomy (ISCAA) and the 1st Paneuropean Meeting for Anatomists (PAM) in Graz from 24th to 26th May 2013. The meetings are held at the Institute of Anatomy at the Medical University of Graz, an institute which is focused on macroscopical and clinical anatomy and well known internationally.

The 5th ISCAA meeting is a very good opportunity for young anatomists to get first experiences in presentations of posters or lectures. The first steps into the scientific field are very important for all of us and especially young scientists to improve future publications and teaching. It should be an opportunity for young anatomists to meet experienced ones and will hopefully be full of high quality contributions and fruitful discussions. Many topics are an opportunity for all anatomists to submit abstracts and to come to Graz to present their scientific results.

The 1st PAM represents a revitalization of the original "Alpenländisches Anatomentreffen" which was held for the last time in Kötschach-Mauthen (Austria) in 1998. The meeting should be regarded as an invitation to Anatomists of all Europe and the entire World to build up and cultivate social and professional networks as well as friendships. Therefore, the social program is also that important but the scientific one. We hope that the symposium and meeting can be of great use of all participants in scientific and private field.

Therefore it is a great honor, to invite you to Graz, Austria, a small but beautiful city with Mediterranean and medieval ambience, a young city with several universities which waits to be explored by you.

We are looking forward seeing you in Graz,

oProf. Dr. med. univ. Dr. hc. Friedrich Anderhuber

Congress President

Head for Department of the Institute of Anatomy, Medical University of Graz

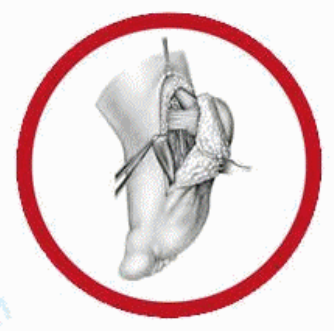




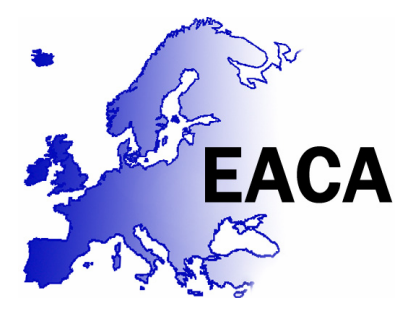

\title{
EUROPEAN ASSOCIATION OF CLINICAL ANATOMY
}

\author{
Univ.Prof. Dr.med. Andreas H. WEIGLEIN \\ EACA-Councilor \& International Congress Coordinator \\ Institute of Anatomy, Vice Chair \\ Medical University Graz \\ Harrachgasse 21, A-8010 Graz, Austria, Europe \\ Tel.: ++433163804210 Fax: ++433163809620 \\ e-mail: andreas.weiglein@medunigraz.at
}

2011-08-02

Dear Mrs. Ex-President Prof. Biasutto,

Dear Council Members of the AAAC,

Dear Members of the AAAC,

The $12^{\text {th }}$ Congress of the European Association of Clinical Anatomy (EACA) will take place in Lisboa, Portugal in the first half of July, 2013. The congress will be organized by Prof. Dr. Antonio Jose Goncalves-Ferreira and his team.

It is with great pleasure that I, on behalf of the EACA-Council and on behalf of the Congress Organising Team invite you - the members of the Asociación Argentina de Anatomía Clínica - to participate and contribute to this international congress that covers a wide variety of topics like clinical anatomy, functional histology, sports anatomy, kinesiolgy, anatomical techniques, and anatomical basis for anaesthesiology, surgery and radiology and medical education.

After more than five years of the AAAC it should be a good idea to join other international groups to see that we are facing similar challenges worldwide, but strategies may be different. And finally, the larger the group the stronger we are.

I wish you a very nice, interesting and fruitful congress in Tucuman. I am deeply sorry that I cannot be with you, but I have to run a surgical training course on the spine with 180 international participants at the same time of your conference.

Yours sincerely,

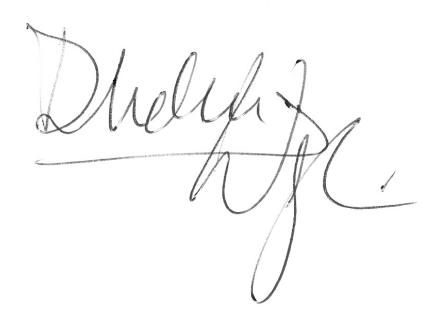

Andreas H. WEIGLEIN

EACA Councilor \& International Congress Coordinator 